\title{
Pengaruh PAD dan DAU Terhadap Belanja Modal Pada Pemerintah Daerah Kabupaten/Kota di Sumatera Selatan
}

\author{
Muhammad Fahmi ${ }^{1}$, Hairani ${ }^{2}$ \\ ${ }^{1}$ Akuntansi, Fak.Ekonomi dan Bisnis Universitas Muhammadiyah Palembang,fahmsulai@yahoo.com \\ ${ }^{2}$ Akuntansi, Fak.Ekonomi dan Bisnis Universitas Muhammadiyah Palembang, hairania145@ymail.com
}

\begin{abstract}
ABSTRAK
Penelitian ini bertujuan untuk mengetahui pengaruh PAD dan DAU terhadap Belanja Modal di Pemerintah daerah Kabupaten/kota di Sumatera Selatan. Penelitian ini menggunakan jenis penelitian assosiatif. Teknik pengumpulan data yang digunakan dalam penelitian ini adalah teknik dokumentasi. Teknik analisis data yang digunakan yaitu analisis kuantitatif. Tehnik analisis data menggunakan regresi linear berganda dengan bantuan SPSS. Hasil penelitian menunjukkan bahwa PAD dan DAU berpengaruh secara bersama dan parsial terhadap Belanja Modal.
\end{abstract}

Kata Kunci : PAD, DAU, Belanja Modal

\section{A. PENDAHULUAN}

Anggaran daerah merupakan rencana keuangan yang menjadi dasar dalam pelaksanaan pelayanan publik. Di Indonesia, dokumen anggaran daerah disebut Anggaran Pendapatan dan Belanja Daerah (APBD), baik untuk propinsi maupun kabupaten/kota. Proses penyusunan anggaran pasca Undang-Undang (UU) 22/1999 dan direvisi menjadi UU $32 / 2004$ melibatkan dua pihak yakni eksekutif dan legislatif, masing-masing melalui sebuah tim panitia anggaran. Adapun eksekutif sebagai pelaksana operasionalisasi daerah, dan berkewajiban membuat draft / rancangan APBD.

Rancangan tersebut hanya bisa diimplementasikan kalau sudah disahkan oleh Dewan Perwakilan Rakyat (DPRD) dalam proses ratifikasi anggaran oleh legislatif. Peranan akuntansi tentunya sangat diperlukan untuk membangun transparasi serta sebagai kontroler terhadap Penggunaan dana APBD.

Dalam APBD terdapat sisi penerimaan dan pengeluaran.
Penerimaan sendiri dapat dibagi menjadi 2 kelompok besar, yaitu pendapatan yang diperoleh dari hasil pengelolaan sumber daya yang ada di daerah Pendapatan Asli Daerah (PAD) dan dana yang di berikan oleh pusat ke daerah yang di sebut Dana Perimbangan terdiri dari Dana Alokasi Umum (DAU), Dana Alokasi Khusus (DAK), Dana Bagi Hasil (DBH) serta Pendapatan Lain- lain yang Sah.

Secara khusus UU No. 32 Tahun 2004 mengatakan salah satu sumber pendapatan daerah adalah PAD yang terdiri dari hasil Pajak Daerah, hasil Retribusi Daerah, hasil pengelolaan kekayaan daerah yang dipisahkan dan lain-lain PAD yang sah. Pemerintah daerah bersama-sama dengan Dewan Perwakilan Rakyat sebagai lembaga legislatif terlebih dahulu menentukan kebijakan umum APBD (KUA) dan Prioritas dan Plafon Anggaran Sementara (PPAS) sebagai pedoman dalam pengalokasian sumber daya ke dalam Anggaran Belanja Modal yang merupakan sebuah proses yang sarat dengan kepentingan politis. Namun dalam proses peningkatan anggaran Belanja Modal yang ada di daerah 
memiliki berbagai macam kendala yang perlu diatasi oleh pemerintah pusat dan daerah.

Belanja modal merupakan pengeluaran yang dilakukan dalam rangka pembelian aset tetap dan asset lainnya yang mempunyai masa manfaat selama 12 bulan digunakan dalam kegiatan pemerintahan, seperti berbentuk tanah, peralatan, mesin, gedung, bangunan, buku perpustakan, hewan dan lain- lain. Alokasi belanja modal ini didasarkan pada kebutuhan daerah akan sarana dan prasarana, baik untuk kelancaran pelaksanaan tugas pemerintahan maupun untuk fasilitas publik. Rendahnya belanja modal merupakan suatu permasalahan karena belanja modal merupakan unsur penting dalam pelayanan publik, administarsi pemerintahan, terlebihnya terhadap suatu perekonomian.

Hasil penelitian Erdi dan

Rachmawati (2015) bahwa

Pendapatan Asli Daerah tidak berpengaruh terhadap Belanja Modal. Dana Alokasi Umum memiliki pengaruh yang positif terhadap Belanja Modal. Hasil penelitian Purpitasari (2015) adalah Pendapatan Asli Daerah dan Dana Alokasi Umum berpengaruh secara signifikan positif terhadap Belanja Daerah. Penelitian Tuasikal (2008) bahwa Dana Alokasi Umum, Dana Alokasi Khusus Pendapatan Asli Daerah berpengaruh positif terhadap belanja modal pemerintah daerah di Indonesia. Penelitian yang dilakukan oleh Fahri dan Winston (2013) bahwa terdapat hubungan yang kurang erat antara Pendapatan Asli Daerah dengan Belanja Modal. Masing-masing Dana Alokasi Umum, dan Dana Alokasi Khusus terdapat hubungan yang sangat erat dengan Belanja Modal.

Pemerintah Daerah yang berhasil menjalankan pembangunan daerah dan meningkatkan kesejahteraan rakyat tidak dapat dilepaskan dari keberhasilan mengelola APBD secara efektif dan efisien. Sebaliknya, pengelolaan APBD yang buruk dapat menghambat kinerja pemerintah daerah dalam peningkatan pembangunan daerah dan kesejahteraan rakyat. Persoalan yang muncul adalah saat pemerintah daerah dihadapkan pada jumlah belanja daerah yang kecil tetapi harus menanggung kebutuhan besar. Sementara pada saat bersamaan pemda kurang memiliki kreativitas mengelola APBD, sehingga pemerintah pada jenjang di atasnya (pemprov atau pusat) tidak optimal dalam mengelola APBD.

\section{B. KAJIAN PUSTAKA}

\section{Anggaran}

Anggaran adalah perencanaan keuangan untuk masa depan yang pada umumnya mencakup jangka waktu satu tahun dan dinyatakan dalam satuan moneter (Mahsun, 2016).

\section{Fungsi anggaran}

Fungsi anggaran sektor publik dibagi menjadi 8 , antara lain sebagai berikut anggaran sebagai alat perencanaan (planning tool), anggaran Sebagai Alat Pengendalian (Control Tool), anggaran Sebagai Alat Kebijakan Fiskal (Fiscal tool), anggaran Sebagai Alat Politik (Political Tool), anggaran Sebagai Alat Koordinasi dan Komunikasi (Coordinator and Communication), anggaran Sebagai Alat Penilaian Kinerja (Performance Measurement Tool), anggaran Sebagai Alat Motivasi (Motivation Tool), anggaran Sebagai alat Untuk Menciptakan Ruang Publik (publik Sphere), anggaran publik tidak boleh diabaikan oleh kabinet, birokrat, dan DRP/DPRD. Masyarakat dan perguruan tinggi harus pula terlibat 
dalam proses penganggaran publik (Mardiasmo, 2009).

\section{Aspek-aspek Anggaran Sektor Publik}

Tahap penganggaran menjadi sangat penting karena anggaran yang tidak efektif dan tidak berorientasi pada kinerja akan dapat menggagalkan perencanaan yang telah disusun. Adapun aspek-aspek yang harus tercakup dalam anggaran sektor publik meliputi aspek perencanaan, aspek pengendalian, aspek akuntabilitas publik (Mardiasmo, 2009).

\section{Jenis-jenis Anggaran Sektor Publik}

Jenis-jenis anggaran sektor publik dibagi menjadi dua, yaitu anggaran Operasional (Operation Recurrent Budget), anggaran Modal investasi (Capital Investasi Budget).

\section{Pendapatan Asli Daerah}

Menurut UU No. 33 Tahun 2004 pasal 1 ayat (13) PAD adalah pendapatan yang diperoleh Daerah yang dipungut berdasarkan Peraturan Daerah sesuai dengan peraturan perundang-undangan.

PAD merupakan pendapatan daerah yang berasal dari sumber-sumber penerimaan murni daerah. PAD dipergunakan untuk pembiayaan penyelenggaraan otonomi daerah.

\section{Dana Alokasi Umum}

Dana alokasi umum menurut UU Nomor 33 Tahun 2004 adalah dana yang bersumber dari pendapatan APBN yang dialokasikan dengan tujuan pemerataan kemampuan keuangan antar-Daerah untuk mendanai kebutuhan Daerah dalam rangka pelaksanaan desentralisasi. Dana alokasi umum (DAU) diberikan pemerintah pusat untuk membiayai kekurangan dari pemerintah daerah dalam memanfaatkan PAD-nya.

\section{Belanja Modal}

Belanja adalah semua pengeluaran dari rekening kas umum negara/daerah yang mengurangi saldo anggaran lebih dalam periode tahun anggaran bersangkutan yang tidak akan diperoleh pembayarannya kembali oleh pemerintah. (PSAP No.2, paragraf 7).

Belanja modal menurut PSAP No.2 paragraf 7 adalah pengeluaran anggaran untuk perolehan aset tetap dan aset lainnya yang memberikan manfaat lebih dari satu periode akuntansi. Belanja modal meliputi antara lain belanja modal untuk perolehan tanah, gedung dan bangunan, peralatan, serta aset tak berwujud.

Belanja modal dimaksudkan untuk mendapatkan aset tetap pemerintah daerah, yakni peralatan, bangunan, infrastruktur, dan harta tetap lainnya. Secara teoritis ada tiga cara untuk memperoleh aset tetap tersebut, yakni membangun sendri, menukarkan dengan aset tetap lain, dan membeli. Namun, untuk kasus dipemerintahan biasanya cara yang dilakukan dengan cara membeli. Proses pembelian yang dilakukan umumnya dilakukan melalui sebuah proses lelang atau teneder yg cukup rumit.

\section{Hipotesis}

Hipotesis dapat dirumuskan sebagai berikut:

$\mathrm{H}_{1}$ :Pendapatan asli daerah $\left(\mathrm{X}_{1}\right)$ berpengaruh positif terhadap belanja modal (Y) pada Pemerintahan daerah kabupaten/kota di sumatera Selatan.

$\mathrm{H}_{2}$ :Dana alokasi umum $\left(\mathrm{X}_{2}\right)$ berpengaruh negatif terhadap belanja modal (Y) pada Pemerintahan daerah 
kabupaten/kota di sumatera Selatan.

$\mathrm{H}_{3}$ :Pendapatan asli daerah $\left(\mathrm{X}_{1}\right)$ dan Dana alokasi umum $\left(\mathrm{X}_{2}\right)$ secara bersama-sama diduga berpengaruh signifikan terhadap belanja modal (Y) pada Pemerintahan daerah kabupaten/kota di sumatera Selatan.

\section{METODE PENELITIAN}

Jenis penelitian yang digunakan dalam penelitian ini adalah penelitian asosiatif/Hubungan yaitu bertujuan untuk mengetahui hubungan dua variabel atau lebih yaitu pendapatan asli daerah dan dana alokasi umum terhadap belanja modal.

Penelitian ini dilakukan pada Kabupaten/kota di Provinsi Sumatera Selatan dimana data diperoleh dari dokumen Laporan Realisasi APBD yang diperoleh dari situs Dirjen Perimbangan Keuangan Pemerintah Daerah (www.djpk.depkeu.go.id). Operasional variabel adalah definisi yang diberikan kepada suatu variabel dengan cara memberikan arti atau menspesifikasikan bagaimana variabel tersebut diukur.

Operasional variabel dalam penelitian ini adalah PAD $\left(\mathrm{X}_{1}\right)$, DAU $\left(\mathrm{X}_{2}\right)$ Belanja Modal $(\mathrm{Y})$.Jenis data yang digunakan dalam penelitian ini, yaitu data sekunder. Data sekunder yang bersumber dari Laporan Realisasi APBD pemerintahan daerah/kota Sumatera Selatan yang diperoleh dari website Dirjen Perimbangan Keuangan Pusat dan Daerah.

Data yang digunakan dalam penelitian ini adalah data 3 tahun yaitu tahun 2013 - 2015. Metode pengumpulan data yang digunakan dalam penelitian ini adalah teknik dokumentasi yaitu dengan mengunduh dan mengumpulkan Laporan Realisasi APBD pemerintahan daerah/kota Sumatera Selatan yang diperoleh dari website Dirjen Perimbangan Keuangan Pusat dan Daerah.

Metode analisis data yang digunakan penulis dalam penelitian ini adalah analisis kuantitatif bertujuan untuk menganalisis dengan menggunakan data berbentuk angka dari data penelitian ini, yakni dengan mengolah data laporan realisasi APBD pemerintahan daerah kabupaten/kota di Sumatera Selatan dengan program Statistica Program for Special Science (SPSS) versi 20.

\section{HASIL PENELITIAN DAN PEMBAHASAN \\ 1. Statistik Deskriptif}

Data yang diambil dalam penelitian ini adalah 52 dari 17 Kabupaten/Kota 1 Provinsi dalam waktu 3 tahun.Dari tabel 1 menunjukkan hasil statistik deskriptif yaitu nilai maksimum rata-rata, dan deviasi standar (standar deviasi) dari variabel-variabel penelitian.Variabelvariabel tersebut meliputi Pendapatan Asli Daerah, Dana Alokasi Umum dan Belanja Modal.

\section{Tabel 1. Hasil Statistik Deskriptif} Descriptive Statistics

\begin{tabular}{|l|r|r|r|r|r|}
\hline & \multicolumn{1}{|c|}{$\mathrm{N}$} & \multicolumn{1}{c|}{ Minimum } & Maximum & \multicolumn{1}{c|}{ Mean } & Std. Deviation \\
\hline PAD & 52 & 1502.00 & 2784967.00 & 239814.6154 & 590012.65113 \\
DAU & 52 & 110387.00 & 1210605.00 & 576871.3654 & 255920.92663 \\
BM & 52 & 141041.00 & 1676693.00 & 449237.2308 & 317812.63890 \\
Valid N (listwise) & 52 & & & & \\
\hline
\end{tabular}

Sumber: Hasil Pengolahan Data, 2017 
Dari pengujian statistik deskriptif pada tabel 1 di atas menunjukkan PAD memiliki nilai rata-rata (mean) sebesar 239814,6154, standar deviasi sebesar 590012,65113. Nilai minimum PAD adalah sebesar 1502,00 dicapai oleh Kab. Musi Rawas Utara pada tahun 2014, nilai maksimum sebesar 2784967,00 dicapai oleh Provinsi Sumsel di tahun 2015. Hal ini berarti bahwa dalam periode penelitian, terdapat nilai tertinggi yang mencapai dalam PAD sebesar 2784967,00 dan PAD minimum sebesar 1502,00 serta rata-rata indeks pengungkapan sebesar 239814,6154.

Dari pengujian statistik deskriptif diketahui DAU memiliki nilai rata-rata (mean) sebesar 576871,3654, standar deviasi sebesar 255920,92663. Nilai minimum DAU adalah sebesar 110387,00 dicapai oleh Kab. Penukal Abab Lematang Ilir pada tahun 2014, nilai maksimum sebesar 1210605,00 dicapai oleh kota Palembang di tahun 2015. Hal ini berarti bahwa dalam periode penelitian, terdapat nilai tertinggi yang mencapai dalam DAU sebesar 1210605,00 dan DAU minimum sebesar 110387,00 serta rata-rata indeks pengungkapan sebesar 576871,3654 .

Dari pengujian statistik deskriptif diketahui Belanja Modal memiliki nilai rata-rata (mean) sebesar 449237,2308, standar deviasi sebesar 317812,63890 . Nilai minimum Belanja Modal adalah sebesar 141041.00 dicapai oleh Kab. Penukal Abab Lematang Ilir pada tahun 2014, nilai maksimum sebesar 1676693,00 dicapai oleh Provinsi Sumsel di tahun 2015. Hal ini berarti bahwa dalam periode penelitian, terdapat nilai tertinggi yang mencapai dalam Belanja Modal sebesar 1676693,00 dan PAD minimum sebesar 141041.00 serta rata-rata indeks pengungkapan sebesar 449237,2308.

\section{Uji Asumsi Klasik}

Uji normalitas dalam penelitian ini dibantu dengan SPSS 20 dengan hasil sebagai berikut :

\section{Gambar 1. Hasil Uji Normalitas P-P Plot}

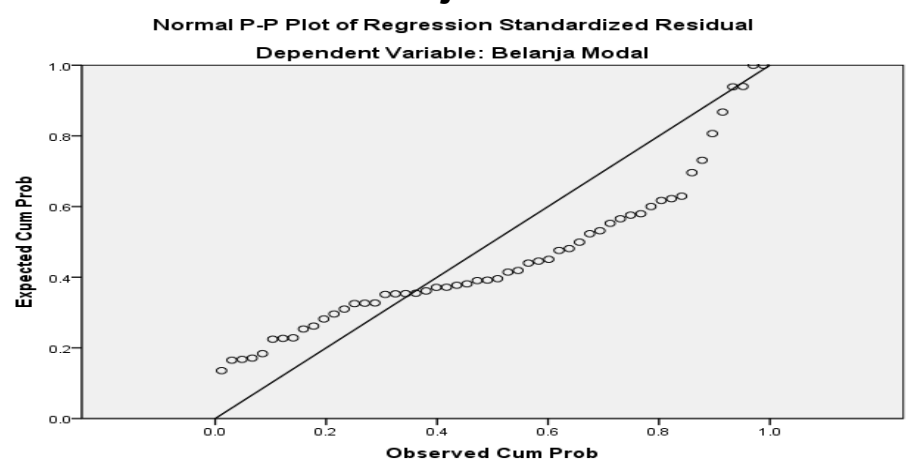

Sumber: Hasil Pengolahan Data, 2017

Berdasarkan gambar 1 tampak titik-titik menyebar disekitar garis diagonal dan mengikuti garis diagonal menunjukkan pola distribusi normal, maka dapat dinyatakan bahwa seluruh data dalam penelitian ini dinyatakan normal.

\section{Uji Multikolonieritas}

Uji multikolonieritas dalam penelitian ini dibantu dengan SPSS 20 dengan hasil sebagai berikut: 
Tabel 2. Hasil Uji Multikolonieritas

Coefficients $^{a}$

\begin{tabular}{|c|c|c|c|c|c|c|c|}
\hline \multirow[b]{2}{*}{ Model } & \multicolumn{2}{|c|}{$\begin{array}{c}\text { Unstandardized } \\
\text { Coefficients }\end{array}$} & \multirow{2}{*}{\begin{tabular}{|c|}
$\begin{array}{c}\text { Standardized } \\
\text { Coefficients }\end{array}$ \\
Beta \\
\end{tabular}} & & \multirow[b]{2}{*}{ Sig. } & \multicolumn{2}{|c|}{$\begin{array}{c}\text { Collinearity } \\
\text { Statistics }\end{array}$} \\
\hline & $B$ & Std. Error & & & & Tolerance & VIF \\
\hline 1 (Constant) & 228102.292 & 72476.099 & & 3.147 & .003 & & \\
\hline PAD & .041 & .009 & .514 & 4.743 & .000 & .927 & 1.079 \\
\hline DAU & .339 & .120 & .307 & 2.826 & .007 & .927 & 1.079 \\
\hline
\end{tabular}

a. Dependent Variable: Belanja Modal

Sumber: Data yang telah diolah menggunakan SPSS

Berdasarkan tabel 2 variabel independen PAD dan DAU memiliki nilai VIF prediktor kurang dari $10(\mathrm{VIF}<$ 10) dan nilai Tolerance lebih dari 0,10 (Tolerarance $>0,10$ ). Hal ini menunjukkan bahwa variabel-variabel dalam penelitian ini bebas dari multikolinearitas.

\section{Uji Heteroskedastisitas}

Uji heteroskedastisitas dalam penelitian ini dibantu dengan SPSS 20 dengan hasil sebagai berikut:

\section{Gambar 2.Hasil Uji Heteroskedestisitas}

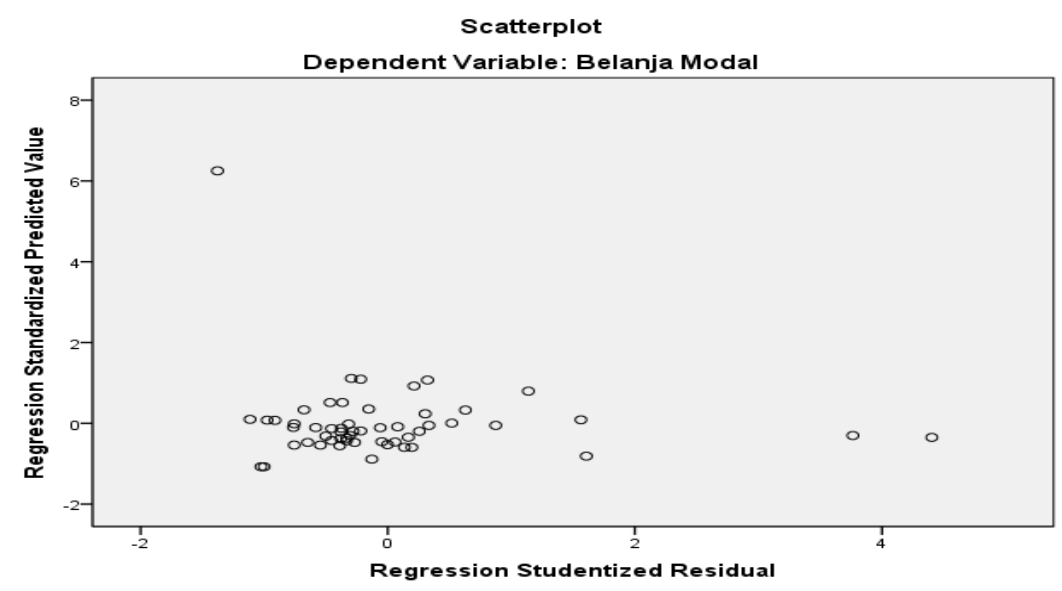

Sumber: Hasil Pengolahan Data, 2017

Dengan melihat diagram Scatterplot pada gambar 2 antara nilai prediksi variabel dependen dengan residualnya diperoleh hasil tidak adanya pola yang jelas dan titik-titik menyebar diatas dan dibawah angka 0 pada sumbu $\mathrm{Y}$, maka tidak terjadi masalah heteroskedastisitas.

\section{Uji Autokorelasi}

Uji Durbin Watson dalam penelitian ini dibantu dengan SPSS 21 dengan hasil sebagai berikut: 
Tabel 3.Hasil Uji Autokolinieritas

Model Summary

\begin{tabular}{|l|l|r|r|r|r|}
\hline Model & $\mathrm{R}$ & $\mathrm{R}$ Square & $\begin{array}{c}\text { Adjusted R } \\
\text { Square }\end{array}$ & $\begin{array}{c}\text { Std. Error of the } \\
\text { Estimate }\end{array}$ & $\begin{array}{c}\text { Durbin- } \\
\text { Watson }\end{array}$ \\
\hline 1 & $.666^{\mathrm{a}}$ & .444 & .422 & 230515.88999 & 1.770 \\
\hline
\end{tabular}

a. Predictors: (Constant), Dana Alokasi Umum, Pendapatan Asli Daerah

b. Dependent Variable: Belanja Modal

Sumber: Hasil Pengolahan Data, 2017

Berdasarkan tabel 3 diketahui nilai DW yaitu 1,770 selanjutnya nilai ini akan dibandingkan dengan nilai tabel Durbin Watson dimana jumlah sampel $\mathrm{N}=18$ dan jumlah variabel independen $\mathrm{K}=3$ maka diperoleh $\mathrm{du}=$ 1,696 dan 4-du= 2,304 maka ditarik kesimpulan du $<$ DW $<4$-du berarti tidak ada masalah autokorelasi.

\section{Uji Koefisien Determinasi (Adjusted R Square)}

Uji koefisien determinasi $(R$ Square) digunakan untuk mengetahui besaran nilai korelasi antara variabel $X$ yang terdiri dari PAD $\left(\mathrm{X}_{1}\right)$ dan DAU $\left(\mathrm{X}_{2}\right)$ dan variabel $\mathrm{Y}$ yakni BM. Tabel IV.6 meupakan output yang dihasilkan uji $R$-Square yang diolah dengan menggunakan program SPSS.

\section{Tabel 4. Hasil Uji Koefisien Determinansi}

\begin{tabular}{|l|l|r|r|r|c|}
\multicolumn{8}{|c|}{ Model Summary } \\
\hline Model & $\mathrm{R}$ & R Square & $\begin{array}{c}\text { Adjusted R } \\
\text { Square }\end{array}$ & $\begin{array}{c}\text { Std. Error of the } \\
\text { Estimate }\end{array}$ & $\begin{array}{c}\text { Durbin- } \\
\text { Watson }\end{array}$ \\
\hline 1 & $.666^{\mathrm{a}}$ & .444 & .422 & 230515.88999 & 1.770 \\
\hline
\end{tabular}

a. Predictors: (Constant), Dana Alokasi Umum, Pendapatan Asli Daerah

b. Dependent Variable: Belanja Modal

Sumber: Hasil Pengolahan Data, 2017

Berdasarkan table 4 diketahui bahwa nilai Adjusted $\mathrm{R}$ Square adalah sebesar 0,422 yang berarti bahwa strukrur modal yang terdiri dari PAD dan DAU mempengaruhi sebesar $42 \%$ terhadap BM, sisanya sebesar $58 \%$ dapat dipengaruhi oleh variabel lain yang tidak dibahas dalam penelitian ini.

\section{Analisis Regresi Linier Berganda}

Analisis regresi linier berganda digunakan untuk mengetahui hubungan antara variabel bebas yaitu variabel PAD dan DAU dengan variabel terikat yaitu BM apakah masing-masing berhubungan positif atau negatif dan untuk memprediksi nilai dari variabel independen mengalami kenaikan atau penurunan. Berikut hasil uji linier berganda: 


\section{Tabel 5.Hasil Uji Regresi Linier Berganda}

Coefficients $^{\mathrm{a}}$

\begin{tabular}{|c|c|c|c|c|c|c|c|}
\hline \multirow[b]{2}{*}{ Model } & \multicolumn{2}{|c|}{$\begin{array}{l}\text { Unstandardized } \\
\text { Coefficients }\end{array}$} & \multirow{2}{*}{$\begin{array}{c}\begin{array}{c}\text { Standardized } \\
\text { Coefficients }\end{array} \\
\text { Beta }\end{array}$} & \multirow[b]{2}{*}{$\mathrm{T}$} & \multirow[b]{2}{*}{ Sig. } & \multicolumn{2}{|c|}{$\begin{array}{l}\text { Collinearity } \\
\text { Statistics }\end{array}$} \\
\hline & B & Std. Error & & & & Tolerance & VIF \\
\hline 1 (Constant) & 228102.292 & 72476.099 & & 3.147 & .003 & & \\
\hline PAD & .041 & .009 & .514 & 4.743 & .000 & .927 & 1.079 \\
\hline DAU & .339 & .120 & .307 & 2.826 & .007 & .927 & 1.079 \\
\hline
\end{tabular}

a. Dependent Variable: Belanja Modal

Sumber: Hasil Pengolahan Data, 2017

Dari hasil regresi linier berganda yang peneliti lakukan pada variabel struktur modal PAD $\left(X_{1}\right)$, dan DAU $\left(\mathrm{X}_{2}\right)$ terhadap profitabilitas BM $(\mathrm{Y})$ dapat digambarkan persamaan regresi sederhana sebagai berikut :

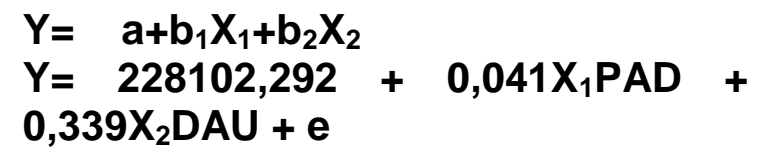

Berdasarkan Uji Regresi linier berganda diatas dapat disimpulkan bahwa:

1) Nilai koefisien regresi $P A D \quad\left(X_{1}\right)$ terhadap profitabilitas $\mathrm{BM}(\mathrm{Y})$ adalah sebesar $0,041 \% \quad(4,1 \%)$. Berarti bahwa PAD $\left(X_{1}\right)$ memiliki hubungan dengan profitabilitas BM (Y) yaitu sebesar 4,1\%, artinya jika ada kenaikan PAD $\left(X_{1}\right)$ sebesar $100 \%$ maka akan meningkatkan profitabilitas BM (Y) sebesar 4,1\%, begitu juga sebaliknya jika ada penurunan PAD $\left(X_{1}\right) \quad 100 \%$ maka akan menurunkan profitabilitas BM (Y) sebesar $4,1 \%$.

2) Nilai koefisien regresi $\mathrm{DAU}\left(\mathrm{X}_{2}\right)$ terhadap profitabilitas BM (Y) adalah sebesar 0,339 (33,9\%). Berarti bahwa DAU $\left(\mathrm{X}_{2}\right)$ memiliki hubungan dengan profitabilitas BM (Y) yaitu sebesar $33,9 \%$, artinya jika ada penurunan DAU $\left(\mathrm{X}_{2}\right)$ sebesar $100 \%$ maka akan menurunkan profitabilitas BM (Y) sebesar 33,9\%, begitu juga sebaliknya jika ada kenaikan DAU $\left(X_{2}\right) \quad 100 \%$ maka akan meningkatkan profitabilitas BM (Y) sebesar 33,9\%.

\section{Uji Hipotesis}

a) Uji Parsial (Uji t)

Uji $t$ dilakukan dengan membandingkan signifikansi thitung dengan ttabel, dengan ketentuan sebagai berikut:

1) $\mathrm{H}_{0}$ diterima dan $\mathrm{H}_{\mathrm{a}}$ di tolak jika $t_{\text {hitung }}<t_{\text {tabel }}$ untuk $\alpha=0,05$

2) $\mathrm{H}_{0}$ ditolak dan $\mathrm{H}_{\mathrm{a}}$ diterima jika $t_{\text {hitung }}>t$ tabel untuk $\alpha=0,05$

Untuk menjawab pertanyaan bagaimanakah pengaruh PAD $\left(\mathrm{X}_{1}\right)$ dan DAU $\left(\mathrm{X}_{2}\right)$ terhadap $\mathrm{BM}(\mathrm{Y})$, maka hasilnya diuji dengan menggunakan uji $\mathrm{t}$, dapat dilihat dari tabel 6 : 
Tabel 6.Hasil Uji Parsial (Uji t)

Coefficients $^{a}$

\begin{tabular}{|c|c|c|c|c|c|c|c|}
\hline \multirow[b]{2}{*}{ Model } & \multicolumn{2}{|c|}{$\begin{array}{l}\text { Unstandardized } \\
\text { Coefficients }\end{array}$} & \multirow{2}{*}{$\begin{array}{c}\begin{array}{c}\text { Standardized } \\
\text { Coefficients }\end{array} \\
\text { Beta }\end{array}$} & \multirow[b]{2}{*}{1} & \multirow[b]{2}{*}{ Sig. } & \multicolumn{2}{|c|}{$\begin{array}{l}\text { Collinearity } \\
\text { Statistics }\end{array}$} \\
\hline & $B$ & Std. Error & & & & Tolerance & VIF \\
\hline 1 (Constant) & 228102.292 & 72476.099 & & 3.147 & .003 & & \\
\hline PAD & .041 & .009 & .514 & 4.743 & .000 & .927 & 1.079 \\
\hline DAU & .339 & .120 & .307 & 2.826 & .007 & .927 & 1.079 \\
\hline
\end{tabular}

a. Dependent Variable: Belanja Modal

Sumber: Hasil Pengolahan Data, 2017

1) Pengaruh Pendapatan Asli Daerah PAD $\left(\mathrm{X}_{1}\right)$ secara parsial terhadap Belanja Modal $(\mathrm{Y})$

Hasil uji hipotesis secara parsial diketahui nilai thitung untuk PAD $\left(X_{1}\right)$ sebesar 4,743 sedangkan nilai tabel tingkat signifikan $\alpha=5 \%(0,05)$ serta $\mathrm{df}=$ $\mathrm{n}-\mathrm{k}=(18-3)=15$ diperoleh nilai tabel sebesar 1.753. Jadi dapat disimpulkan bahwa $\mathrm{H}_{01}$ ditolak dan $\mathrm{H}_{\mathrm{a} 1}$ diterima karena nilai thitung $4,743>t_{\text {tabel }}$ 1,753. Hasil uji hipotesis individual untuk variabel PAD $\left(X_{1}\right)$ menunjukkan bahwa variabel tersebut berpengaruh secara signifikan terhadap Belanja Modal (Y). Hal Ini digambarkan dengan diterimanya $\mathrm{Ha} 1$ dan ditolaknya $\mathrm{H}_{01}$ serta nilai signifikan $X_{1}$ 0,000 lebih kecil dari 0,05 . Jadi dapat disimpulkan bahwa PAD $\left(X_{1}\right)$ berpengaruh signifikan secara parsial terhadap Belanja Modal (Y).

2) Pengaruh Dana Alokasi Umum DAU (X2) secara parsial terhadap Belanja Modal $(Y)$

Hasil uji hipotesis secara parsial diketahui nilai thitung untuk DAU $\left(\mathrm{X}_{2}\right)$ sebesar 2.826, sedangkan nilai tabel tingkat signifikan $\alpha=5 \%(0,05)$ serta $d f=$ $n-k=(18-3)=15$ diperoleh nilai tabel sebesar 1.753. Jadi dapat disimpulkan bahwa $\mathrm{H}_{02}$ diterima dan $\mathrm{H}_{\mathrm{a} 2}$ ditolak karena nilai thitung $2.826>$ tabel 1.753. Hasil uji hipotesis individual untuk variabel DAU $\left(X_{2}\right)$ menunjukkan bahwa variabel tersebut berpengaruh signifikan terhadap Belanja Modal (Y). Hal Ini digambarkan dengan diterimanya $\mathrm{H}_{02}$ dan ditolaknya $\mathrm{H}_{\mathrm{a} 2}$ serta nilai signifikan $\mathrm{X}_{2} \quad 0,007$ lebih besar dari 0,05. Jadi dapat disimpulkan bahwa PAD $\left(\mathrm{X}_{2}\right)$ berpengaruh negatif signifikan secara parsial terhadap Belanja Modal (Y).

\section{b) Uji Simultan (Uji f)}

Pengujian hipotesis secara simultan merupakan pengujian hipotesis koefisien regresi berganda dengan $X 1, X 2$, dan $X 3$ secara bersama-sama mempengaruhi $Y$. Untuk menjawab permasalahan pengaruh struktur modal PAD dan DAU terhadap Belanja Modal, maka hasilnya di uji dengan menggunakan uji $f$ yang dilakukan dengan menggunakan Analysis Of Varians (ANOVA). Hasil perhitungan pengujian yang diolah menggunakan SPSS, dapat dilihat pada tabel berikut: 


\section{Tabel 7.Hasil Simultan (Uji F)}

ANOVA $^{b}$

\begin{tabular}{|l|r|r|r|r|r|}
\hline Model & \multicolumn{1}{|c|}{$\begin{array}{c}\text { Sum of } \\
\text { Squares }\end{array}$} & Df & $\begin{array}{c}\text { Mean } \\
\text { Square }\end{array}$ & F & Sig. \\
\hline 1 Regression & $2.164 \mathrm{E} 12$ & 2 & $1.082 \mathrm{E} 12$ & 20.363 & $.000^{\mathrm{a}}$ \\
$\quad$ Residual & $2.710 \mathrm{E} 12$ & 51 & $5.314 \mathrm{E} 10$ & & \\
$\quad$ Total & $4.874 \mathrm{E} 12$ & 53 & & & \\
\hline
\end{tabular}

a. Predictors: (Constant), Dana Alokasi Umum, Pendapatan Asli Daerah

b. Dependent Variable: Belanja Modal

Berdasarkan tabel 7 hasil pengujian uji hipotesis secara simultan diketahui $F_{\text {hitung untuk variabel }}$ independen PAD dan DAU sebesar 20.363 sedangkan nilai $F_{\text {tabel }}$ dengan $\alpha$ $=5 \%(0,05)$ serta $\mathrm{db}=\mathrm{n}-\mathrm{k}-1$, jadi taraf nyata $(\mathrm{db})$ adalah $=18-3-1=14$ sehingga $F_{\text {tabel }}$ adalah sebesar 3,34 . Nilai $F_{\text {hitung }}$ sebesar 20.363> $F_{\text {tabel }}$ 3,34 maka hipotesis $\mathrm{H}_{0}$ ditolak $\mathrm{Ha}$ diterima, dapat disimpulkan bahwa PAD dan DAU berpengaruh secara simultan terhadap Belanja Modal. Berdasarkan kriteria pengujian $\mathrm{H}_{0}$ ditolak karena Fsig $0,000<$ nilai a 0,05. Jadi dapat disimpulkan bahwa PAD dan DAU berpengaruh positif dan signifikan secara simultan terhadap Belanja Modal.

\section{E. KESIMPULAN DAN SARAN \\ 1. Kesimpulan}

Kesimpulan yang dapat penulis peroleh adalah:

a) Hasil uji hipotesis secara parsial diketahui nilai thitung positif untuk PAD $\left(X_{1}\right)$ dengan tingkat signifikan lebih kecil dari a yang ditentukan hal ini berarti PAD berpengaruh positif signifikan terhadap Belanja Modal dan hipotesis diterima. Jadi dapat disimpulkan $\mathrm{Ho} 1$ ditolak dan $\mathrm{Ha} 1$ diterima yang menunjukkan bahwa jika PAD meningkat maka Belanja Modal akan meningkat. b) Nilai thitung negatif untuk DAU $\left(\mathrm{X}_{2}\right)$ dengan tingkat signifikan lebih kecil dari a yang ditentukan hal ini berarti DAU berpengaruh negatif signifikan terhadap Belanja Modal dan hipotesis diterima. Jadi dapat disimpulkan Ho2 ditolak dan Ha2 diterima yang menunjukkan bahawa jika DAU meningkat, maka Belanja Modal meningkat.

c) Hasil uji hipotesis secara simultan diketahui nilai thitung positif untuk PAD $\left(X_{1}\right)$ dan DAU $\left(X_{2}\right)$ dengan tingkat signifikan lebih kecil dari a yang ditentukan hal ini berarti variabel PAD dan DAU berpengaruh positif signifikan terhadap Belanja Modal dan hipotesis diterima. Jadi dapat disimpulkan $\mathrm{Ho}$ ditolak dan Ha1 diterima yang menunjukkan bahwa jika PAD dan DAU meningkat, maka Belanja Modal akan meningkat.

\section{Saran}

Beberapa saran yang perlu dikemukakan adalah meliputi :

a) Dalam menetapkan anggaran belanja modal pemerintah Provinsi Sumatera Selatan, maka harus mempertimbangkan Dana Alokasi Umum dan Pendapatan Asli Daerah.

b) Pengolahan Keuangan dan Aset Daerah sebaiknya meningkatkan kinerja yang telah dilakukan 
sebelumnya khususnya dalam bidang sarana dan prasarana publik terutama pembangunan fasilitas umum agar tercapai secara merata.

c) Pengolahan Keuangan dan Aset Daerah sebaiknya memperbaharui peraturan undang-undang terbaru tentang pendapatan daerah yang berlaku serta harus tranparan terhadap informasi mengenai APBD.

d) Untuk penelitian selanjutnya, sebaiknya peneliti menambahkan variabel yaitu pertumbuhan ekonomi dan indeks pembangunan manusia agar hasilnya lebih baik dari peneliti yang sekarang dilakukan oleh penulis.

\section{DAFTAR PUSTAKA}

Erdi dan Rachmawati. 2015. Pengaruh Pendapatan Asli Daerah dan Dana Alokasi Umum Terhadap Belanja Modal dengan Pertumbuhan Ekonomi sebagai Pemoderasi. Jurnal Akuntansi, Keuangan dan Perbankan, (online), Vol. 4, No. 2, (https://unisbank.ac.id/article/view /4598/2971).

Fahri dan Winston. 2013. Analisis Hubungan Pendapatan Asli Daerah, Dana Alokasi Umum, dan Dana Alokasi Khusus atas Belanja Modal, pada Pemerintah Daerah Kabupaten Tolitoli Provinsi Sulawesi Tengah. Jurnal Akuntansi, (online), Vol. 2, No. 1, (https://ejournal.unsrat.ac.id/index .php/accountability/article/view/23 37/1891)

Mahsun, Muhammad. 2016). Pengukuran Kinerja Sektor Publik. Yogyakarta: Anggota IKAPI.

Mardiasmo. 2009. Akuntansi Sektor Publik. Yogyakarta: CV Andi.

Pernyataan Standar Akuntansi Pemerintah Nomor 02 tentang Laporan Realisasi Anggaran Jakarta: Presiden Republik Indonesia.

Purpitasari, Puput. 2015. Pengaruh pendapatan Asli Daerah dan Dana Alokasi Umum terhadap Alokasi Belanja Daerah. Jurnal IImu dan Riset Akuntansi, (online), Vol.4, No.11, (https://ejournal.stiesia.ac.id/jira/a rticle/view/1108/1069)

Undang-undang Republik Indonesia No. 22 Tahun 1999 tentang Pemerintahan Daerah (1999) Jakarta: Presiden Republik Indonesia.

Undang-undang Republik Indonesia Nomor 32 Tahun 2004 tentang Pemerintahan Daerah (2004) Jakarta: Presiden Republik Indonesia.

Undang-undang Republik Indonesia Nomor 33 Tahun 2004 tentang Perimbangan Keuangan antara Pemerintah Pusat dan Daerah (2004) Jakarta: Presiden Republik Indonesia. 